\title{
The Impact of Asian Economic Policy Uncertainty : Evidence from Korean Housing Market
}

\author{
Ji-Hong Jeon ${ }^{1}$
}

Received: April 12, 2018. Revised: April 22, 2018. Accepted: May 5, 2018.

\begin{abstract}
We study the impact of economic policy uncertainty (EPU) of Asian four countries such as Korea, Japan, Hong Kong, and China on housing market returns in Korea. Also, we document the relationship between the EPU index of those four countries and the housing market including macroeconomic indicators in Korea. The EPU index of those four countries has significantly a negative effect on the housing purchase price index, housing lease price index in Korea. The EPU index in Korea and Japan has significantly a negative effect on the CPI. The EPU index in only Japan has significantly a negative effect on the PPI. The EPU index in Hong Kong and Korea has significantly a negative effect but the EPU index in China significantly has a positive effect on the stock price index in construction industry. The EPU index in only Korea has significantly a negative effect the stock price index in banking industry. This study shows the EPU index of the Korea has the negative relationships on the housing market economy rather than other countries by VECM. And this study has an important evidence of the spillover of several macroeconomic indicators in Korea for the EPU index of the Asian four countries.
\end{abstract}

Keywords: Asian Countries, Economy Policy Uncertainty Index, Housing Market, Stock market, Vector Error Correction Model.

JEL Classification Code: C32, D80, E60, E66, G10, G15.

\section{Introduction}

Housing prices are closely related to national economic policies. Numerous studies supporting this are still continuing. In this study, we examine whether the economic policy uncertainty (EPU) of Asian countries including Korea can affect Korea's economic environment, especially the housing market. Also, if Asian countries have an impact on Korea's housing market, which any country's EPU will has the most impact?

Prior to starting this interesting question, we looked at the information about population density republished from the Central Intelligence Agency (CIA) World Factbook 2017. Korea is one of the most densely populated countries in Asia, including Hong Kong, Japan, etc. According to Ministry of Land, Infrastructure and Transport as of 2016, it takes 6.7 years to purchase the first house for the life in Korea. The Korean people are more interested in purchasing a house than other assets. The economic uncertainty of the country

1 First Author, Adjunct Professor, School of Business, Hanyang University, Seoul, Korea. Tel: +82-2-2220-2435,

E-mail: cellc@hanyang.ac.kr can have a significant impact on the housing market. We examine the impact of this study on the Korean housing market through the EPU of four major Asian powers: Korea, Japan, Hong Kong and China. In particular, Korea is more sensitive to housing economy than other countries because of its high population density. Therefore, the share of housing in the national economy is large. We find out previous studies that the relationship between the national economy and the housing market is intimate. Buckley and Ermisch (1982) use the UK government as an example. If the government had a large involvement in the housing market, it would have a strong influence on the housing market. Englund and loannides (1997) compare housing prices in 15 Organization for Economic Co-operation and Development (OCED) countries, including Sweden, the United Kingdom and the United States, and housing prices are not the main macroeconomic variables, but policy changes, such as tax reforms and credit deregulation, have the greatest impact on housing prices.

Bittlingmayer (1998) report that stock volatility increases if the output decreases. Taking Germany as an example, it is clear that political events are a source of volatility. During the mid and late 1920s, Germany's political stabilization was steadily decreasing volatility and volatility of stocks. He also 
finds that using VAR (vector auto regression), uncertainty has a negative relationship to stock volatility and consumer price index (CPI). According to Bloom (2009), investment and employment are halted and consumption and production are reduced in uncertain times such as the Cuban Missile Crisis and the Organization of the Petroleum Exporting Countries (OPEC) I oil shock. Thus, the impact of this uncertainty has shown a short, rapid decline and recovery.

Beltratti and Morana (2010) study the relationship between macroeconomic conditions and housing prices in the Group of 7 (G-7) countries. Rahman (2010) reports Australia's recent rise in housing prices because of the complexity of various factors, especially as mortgage-based house owners and renters increased in number. In addition, government taxes, land supply and land-use planning systems, and economic climate have contributed to changes in housing prices. Jian (2012) documents the urban consumption in China with Foodstuff, Health care and Housing. Wang and Kim (2014) study the problem of an aging population and reverse mortgages in China by using housing price, interest rate, and so on. Antonakakis and Floros (2016) cite economic variables such as the United Kingdom (UK) housing and stock market, economic policy uncertainty, inflation, and real interest rate. Unexpected severe economic fluctuations such as the financial crisis could lead to uncertainty in the economic situation and real estate investment market. Zhang et al. (2016) study the relationship between house price and house demand. Jeong (2017) examines the credit loan for housing in Korea to explain the household consumption. In this way, we find that there are studies on the economic policy uncertainties and the housing market.

First of all, the EPU index as the indicator of economic policy uncertainties bases on the frequency of the terms in the newspaper, and the EPU index of over 20 countries, including Korea, Japan, Hong Kong and China, is made by Baker et al. (2016). They investigate the relationship between various economic factors such as stock price volatility and employment growth. Aoki et al. (2004) study housing price, consumption and monetary policy in the UK housing market. As a result, the impact of monetary policy increases consumption but lowers the effect of housing prices and housing investment. Also, structural changes in the credit markets have lowered the additional loan transaction costs.

Mei and Guo (2004) study the effects of policy instability on the stock markets of 22 emerging markets, focusing on the financial crisis. As a result, using the probit and switching regression, they find that the stock market volatility increases during political elections. Döpke and Pierdzioch (2006) study the relationship between German politics and stock markets. Using a VAR model, the stock market affects the popularity of the German government. And that the political process has a weak impact on the stock market. Compared with the United State (US), the German stock market did not move much higher during the left government period than the right-wing government. Campbell and Cocoo (2007) use a UK family consumption survey to study the response of consumption to housing prices. As a result, predicted changes in housing prices correlated with consumption forecasts. And more sensitive to lending, affect not only homeowners but also renters, and in the end, UK house prices are closely correlated with the overall financial market.

Backé and Wójcik (2008) study the effects of consumption and monetary policy, which play a pivotal role in credit expansion in the euro area. In particular, the recent lending boom has a strong connection with mortgage-based housing loans and can give the energy to policy makers and new research. lacoviello and Minetti (2008) conduct a study of bank lending related to the housing market in four countries such as Finland, Germany, Norway and the UK. They argue that the credit channel is related to the structural characteristics of the housing finance system, namely efficiency and institutional organization. Using a VAR model, they find that there is a close correlation between the credit channel, the efficiency of housing finance, and the mortgage organization.

Calcagno et al. (2009) study the impact of Italy's household income and consumption behavior on real estate change. An increase in housing prices has led to an increase in consumption for homeowners and tenants. Boutchkova et al. (2012) argue that political uncertainty affects stock market volatility and political risk makes volatility even higher. The industry response to political events is asymmetric. Julio and Yook (2012) study the relationship between the policy instability and corporate investment in 48 countries. They find that it reduces investment spending on companies until policy instability is resolved.

Chang et al. (2015) examine the relationship between the seven OECD countries and the economic uncertainty of each country. The results of the bootstrap panel causality test show that policy uncertainty has a negative impact on industrial production (IP), economic growth, and firm-level investment decisions, which has a negative impact on share prices. Su et al. (2016) find that EPU in Germany has no impact on the housing market. The reason is that the German real estate market has stabilized. A characteristic of social welfare and a reasonable system are provided. However, in an external crisis, the real estate market has an important influence on economic policy choice. 
There are many studies on economic uncertainty and housing in Korea. Chung and Haurin (2002) study the relationship between instability of family size outcome, aftertax income and housing cost. Stochastic economic and demographic variables have influenced housing choice. Yu (2008) studies the impact of housing policy on housing price instability. A decrease in construction orders results in a decrease in housing supply and an increase in house prices. Construction orders show a negative relationship with housing price instability.

The CPI of macroeconomic variables has a significant effect on the home sales price and the lease price. They use Gross Domestic Product (GDP), CPI, and money supply as macroeconomic variables that affect the destabilization of housing prices in Korea. According to the results of the study, corporate bond returns, money supply and building construction permits showed significant results, but the government's housing policy changed several times to stabilize housing, but it had no effect on housing prices. Excessive housing policy has adversely affected the consumers' sense of buying home. The rest of this study is as follows. Section 2 provides an explanation of the data and empirical analysis model, and Section 3 shows the analysis of the model. Section 4 describes the conclusion.

\section{Data and Methodology}

\subsection{Data}

The data used in this study are monthly data for January 1999 to December 2016. The data used in this study are ten variables, and we try to analyze the effect of EPU of Korea, Japan, Hong Kong and China on Korea 's housing market. In addition, there are six macroeconomic variables excluding EPU for the empirical analysis. We use Korea's $\mathrm{CPI}$, Producer Price Index (PPI) that represent Korea's consumption and production. The Housing Purchase Price Index (HPPI) and the Housing Lease Price Index (HLPI) indicate directly trends in the housing market. And the construction stock Index and the banking stock index which indirectly identifies housing market trends are used as variables.

The EPU index of Korea, Japan, Hong Kong and China comes from Baker et al. (2016). As a macroeconomic index, the CPI is obtained from the National Statistical Office of Korea and the PPI is obtained from the Bank of Korea. In addition, the HPPI and HLPI are obtained from Kookmin Bank in Korea, and the construction and banking stock indexes are supplied by FnGuide in Korea.

For the CPI, Dougherty and Order (1982) report CPI as an alternative to home purchase price and mortgage interest cost, along with capital cost, as an index of the minimum expenditure flow needed to support a standard level of welfare. Yu and Lee (2010) study that Korea's CPI is closely related to HPPI and HLPI. Regarding the PPI, Jeon (2017) studies that if the uncertainty of the national economic policy on Korea, the United States and Japan is uncertain, the prices of raw materials such as gold and crude oil rise, and the PPI using the raw materials increases. Fig. 1 illustrates the cycle for CPI, HPPI, HLPI and PPI. Korea's CPI, HPPI, $\mathrm{HLPI}$ and PPI have risen $57 \%, 101 \%, 165 \%$ and $31 \%$ for the last 18 years respectively.

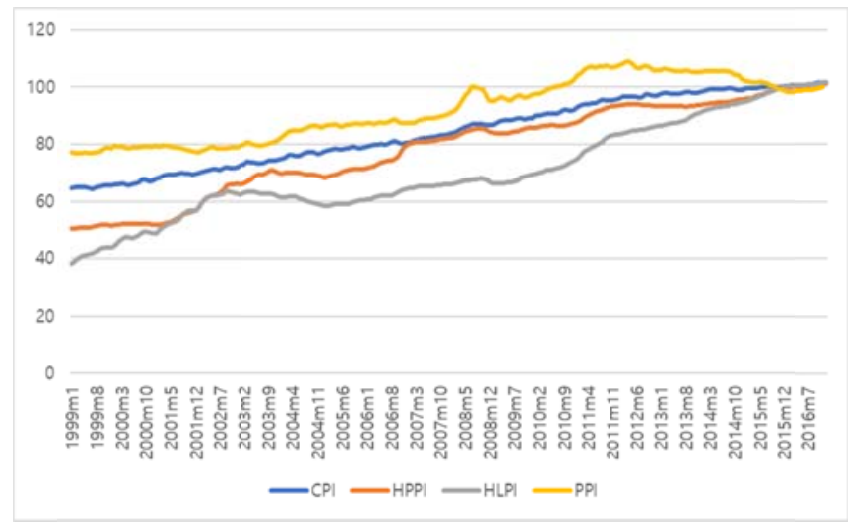

Figure 1. The cycle of the CPI, HPPI, HLPI, and PPI. (1999:012016:12)

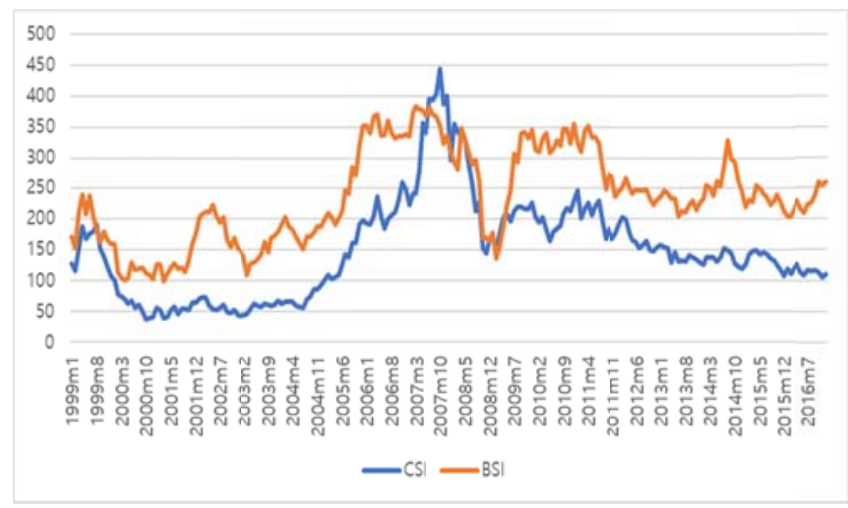

Figure 2. The cycle of the CSI and BSI. (1999:01-2016:12)

As for the stock price index, in Fig. 2, CSI and BSI indirectly predict changes in the housing market through the stock price index that represents the Korean housing market. And we report that CSI and BSI move in the same direction. When the housing market improves, the housing and financial stock indexes are also rising. (Englund \& loannides, 1997). While the EPU index increases, the stock price index can be predicted to decrease. (Antonakakis \& Floros, 2016; Jeon et al., 2017). 
Table 1. Descriptive statistics.

\begin{tabular}{|c|c|c|c|c|c|c|c|c|c|c|}
\hline & $\begin{array}{c}\text { Korea } \\
\text { EPUI }\end{array}$ & EPUI & $\begin{array}{c}\text { Hong } \\
\text { Kong } \\
\text { EPUI }\end{array}$ & $\begin{array}{c}\text { China } \\
\text { EPUI }\end{array}$ & CPI & PPI & HPPI & HLPI & CSI & BSI \\
\hline Mean & 4.696 & 4.618 & 4.635 & 4.686 & 4.425 & 4.518 & 4.340 & 4.225 & 4.857 & 5.411 \\
\hline Median & 4.723 & 4.619 & 4.654 & 4.657 & 4.426 & 4.508 & 4.409 & 4.189 & 4.963 & 5.447 \\
\hline Min. & 3.119 & 3.883 & 3.136 & 2.205 & 4.166 & 4.340 & 3.920 & 3.648 & 3.644 & 4.598 \\
\hline Max. & 5.975 & 5.465 & 5.828 & 6.373 & 4.621 & 4.691 & 4.619 & 4.621 & 6.097 & 5.949 \\
\hline S.D. & 0.475 & 0.292 & 0.554 & 0.655 & 0.145 & 0.117 & 0.216 & 0.239 & 0.576 & 0.346 \\
\hline N & 216 & 216 & 216 & 216 & 216 & 216 & 216 & 216 & 216 & 216 \\
\hline
\end{tabular}

Note: EPUI, CPI, PPI, HPPI, HLPI, CSI, BSI indicate separately Economy Policy Uncertainty Index, Consumer Price Index, Producer Price Index, Housing Purchase Price Index, Housing Lease Price Index, Construction Stock Index, Banking Stock Index.

\subsection{Methodology}

In this study, we use Vector Error Correction Model (VECM) as Equation (1) rather than Vector Auto Regression (VAR) for the empirical analysis through the relationship between cointegration and error correction model proposed by Granger (1981). The reason for using VECM is that the linear combination of abnormal time series variables may look normal as the study of Engle and Granger (1987) which considered whether the system has the equilibrium in the long time and a stationary linear for changes. Therefore, when there is no unit root in the first difference variable but the cointegration relation is found through the cointegration test, it is possible to prevent the information loss that may occur in the first differential using VECM using the level variable.

$$
\Delta Y_{t}=\sum_{i=1}^{s=1} \gamma_{i} \Delta Y_{t-i}+\alpha \beta Y_{t-s}+\psi+\epsilon_{t}
$$

$\Delta$ : first difference operator

$Y_{t}:(\mathrm{p} \times 1)$ vector as variables are $\mathrm{I}(1)$

i: lag order

s: maximum number of lag order

t: time (period)

$\gamma: p \times p$ matrix of short-run coefficients

$\alpha \beta^{\prime} Y_{t-s}$ : lagged error correction term

$\alpha$ : adjustment parameters

$\beta$ : cointegration vectors

$\psi$ : vector of deterministic components

$\epsilon_{t}: \mathrm{p} \times 1$ vector of disturbances

p: EPU Index of Korea, Japan, Hong Kong and China, CPI, PPI, HPPI, HLPI, CSI, BSI.

\section{Empirical Findings}

\subsection{Unit Root Test}

Granger and Newbold (1974) suggest that the unit root test should identify whether there is strong autocorrelation in the monthly residual series. If the time series variable is unstable, there may be a problem with spurious regression. Augmented dickey fuller (ADF) and Phillips-Perron (PP) tests are performed as shown in Table 2. As a result of the unit root test, the level variable that took log data in raw data has a unit root, but there is no unit root in the first difference result. Therefore, the first subordinate time series has stability because there is no unit root.

Table 2. Unit root tests.

\begin{tabular}{|c|c|c|c|c|c|}
\hline & \multicolumn{2}{|c|}{ ADF Test } & \multicolumn{2}{|c|}{ PP Test } \\
\hline & & Level & $\begin{array}{c}1 \text { st } \\
\text { Difference }\end{array}$ & Level & $\begin{array}{c}\text { 1st } \\
\text { Difference }\end{array}$ \\
\hline \multirow{2}{*}{$\begin{array}{l}\text { Korea } \\
\text { EPUI }\end{array}$} & Con. & -4.525 & $-13.548^{* * *}$ & -5.816 & $-22.231^{* * *}$ \\
\hline & $\begin{array}{l}\text { Con. \& } \\
\text { Trend }\end{array}$ & -5.119 & $-13.533^{\star \star *}$ & -6.574 & $-22.188^{* * *}$ \\
\hline \multirow{2}{*}{$\begin{array}{l}\text { Japan } \\
\text { EPUI }\end{array}$} & Con. & -4.605 & $-12.855^{\star \star *}$ & -5.061 & $-20.911^{* * *}$ \\
\hline & $\begin{array}{l}\text { Con. \& } \\
\text { Trend }\end{array}$ & -4.819 & $-12.838^{* * *}$ & -5.300 & $-20.889^{* * *}$ \\
\hline \multirow{2}{*}{\begin{tabular}{|l|} 
Hong \\
Kong \\
EPUI \\
\end{tabular}} & Con. & -5.004 & $-16.002^{* * *}$ & -6.530 & $-24.907^{* * *}$ \\
\hline & $\begin{array}{l}\text { Con. \& } \\
\text { Trend }\end{array}$ & -8.073 & $-15.997^{* * *}$ & -9.741 & $-24.852^{* * *}$ \\
\hline \multirow[b]{2}{*}{$\begin{array}{l}\text { China } \\
\text { EPUI }\end{array}$} & Con. & -4.445 & $-17.481^{* \star *}$ & -6.885 & $-28.908^{* * *}$ \\
\hline & $\begin{array}{l}\text { Con. \& } \\
\text { Trend }\end{array}$ & -5.885 & $-17.456^{\star * *}$ & -8.770 & $-28.914^{* * *}$ \\
\hline \multirow[b]{2}{*}{ CPI } & Con. & 552 & $1.991^{* \star \star}$ & -2.037 & $-10.892^{* * *}$ \\
\hline & $\begin{array}{l}\text { Con. \& } \\
\text { Trend }\end{array}$ & -0.821 & $-12.192^{* * *}$ & 0.283 & $-11.071^{* * *}$ \\
\hline \multirow[b]{2}{*}{ PPI } & Con. & -1.151 & $-7.305^{* * *}$ & -1.097 & $-7.463^{* \star *}$ \\
\hline & $\begin{array}{l}\text { Con. \& } \\
\text { Trend }\end{array}$ & -1.449 & $-7.333^{* * *}$ & -0.856 & $-7.464^{* * *}$ \\
\hline \multirow[b]{2}{*}{ HPPI } & Con. & -1.729 & $-7.221^{* * *}$ & -2.096 & $-5.224^{* * *}$ \\
\hline & $\begin{array}{l}\text { Con. \& } \\
\text { Trend }\end{array}$ & -1.694 & $-7.461^{* * *}$ & -1.094 & $-5.396^{\star \star \star}$ \\
\hline \multirow[b]{2}{*}{ HLPI } & Con. & -2.285 & $-9.791^{* * *}$ & -2.778 & $-4.981^{* * *}$ \\
\hline & $\begin{array}{l}\text { Con. \& } \\
\text { Trend }\end{array}$ & -3.345 & $-10.165^{\star * *}$ & -3.083 & $-5.206^{\star * *}$ \\
\hline \multirow[b]{2}{*}{ CSI } & Con. & -1.343 & $-11.952^{* * *}$ & -1.456 & $-15.584^{* * *}$ \\
\hline & $\begin{array}{l}\text { Con. \& } \\
\text { Trend }\end{array}$ & -1.461 & $-11.904^{* * *}$ & -1.598 & $-15.539^{* * *}$ \\
\hline \multirow[b]{2}{*}{ BSI } & Con. & -2.102 & $-10.338^{* \star *}$ & -2.273 & $-14.618^{* * *}$ \\
\hline & $\begin{array}{l}\text { Con. \& } \\
\text { Trend }\end{array}$ & -2.396 & $-10.312^{\star \star *}$ & -2.622 & $-14.587^{* \star *}$ \\
\hline
\end{tabular}

Notes: 1. EPUI, CPI, PPI, HPPI, HLPI, CSI, BSI indicate separately Economy Policy Uncertainty Index, Consumer Price Index Producer Price Index, Housing Purchase Price Index, Housing Lease Price Index, Construction Stock Index, Banking Stock Index.

2. ADF and PP denote Augmented Dickey-Fuller and Phillips-Perron respectively. 
3. Con, Con. \& Trend denote constant, and constant and trend separately.

4. ${ }^{* * *},{ }^{* *},{ }^{*}$ mean $1 \%, 5 \%, 10 \%$ levels.

\subsection{Cointegration Test}

The cointegration test developed by Johansen (1988) is used to confirm whether there is a cointegration relation in time series. Johansen test is divided into Trace statistic and Maximum eigen value $(\lambda \max )$. Ho is a hypothesis that there is no cointegration. As a result of the cointegration test in Table 3, the cointegration exists, and the VECM, rather than the VAR, is used for the empirical analysis.

Table 3. Cointegration test.

\begin{tabular}{|c|c|c|c|c|}
\hline Ho & Trace & $\begin{array}{c}\text { 5\% Critical } \\
\text { Value }\end{array}$ & ëmax & $\begin{array}{c}\text { 5\% Critical } \\
\text { Value }\end{array}$ \\
\hline$r=0$ & 679.90 & 233.13 & 196.55 & 62.81 \\
\hline$r \leq 1$ & 483.34 & 192.89 & 137.58 & 57.12 \\
\hline$r \leq 2$ & 345.76 & 156.00 & 107.33 & 51.42 \\
\hline$r \leq 3$ & 238.43 & 124.24 & 84.40 & 45.28 \\
\hline$r \leq 4$ & 154.02 & 94.15 & 72.58 & 39.37 \\
\hline$r \leq 5$ & 81.43 & 68.52 & 28.48 & 33.46 \\
\hline$r \leq 6$ & 52.94 & 47.21 & 23.95 & 27.07 \\
\hline$r \leq 7$ & $28.99^{*}$ & 29.68 & 15.59 & 20.97 \\
\hline
\end{tabular}

Note: * means $p<0.05$.

\subsection{Granger Causality Test}

Through the Granger causality test by Granger (1980), we examine the effects of EPU index in the four countries on the Korean economy. In Table 4, if the null hypothesis ( $\mathrm{Ho}$ ) is significant, the EPU index of four countries and the Korean economic index variables, it is rejected, and the alternative hypothesis is adopted. As a result of the Granger causality test, Korea EPU index has a causal relationship valid for CPI, HPPI, HLPI, and BSI. Conversely, PPI, HLPI has a causal relationship valid for Korea EPU index. Japan EPU index has a causal relationship available to HPPI, HLPI BSI. On the contrary, only HPPI has a causal relationship valid for Japan EPU index. Hong Kong EPU index has a causal relationship valid for all other Korean economic index variables except PPI. On the other hand, only HLPI and BSI had a causal relationship valid for Hong Kong EPU index. China EPU index had a causal relationship to all other economic index variables except $\mathrm{CPI}$ and PPI. All other economic index variables except $\mathrm{CPI}$ and CSI had a causal relationship valid for China EPU index.

\subsection{VECM}

Table 4. Granger causality tests.

\begin{tabular}{|c|c|c|}
\hline & Ho & Chi-sq \\
\hline \multirow{2}{*}{$\begin{array}{c}\text { CPI \& Korea } \\
\text { EPUI }\end{array}$} & $\mathrm{CPI} \nRightarrow$ Korea EPUI & 0.961 \\
\hline & Korea EPUI $\nRightarrow \mathrm{CPI}$ & $11.402^{* * *}$ \\
\hline \multirow{2}{*}{$\begin{array}{c}\text { PPI \& Korea } \\
\text { EPUI }\end{array}$} & $\mathrm{PPI} \nRightarrow$ Korea EPUI & $13.070^{* * *}$ \\
\hline & Korea EPUI $\nRightarrow$ PPI & 0.078 \\
\hline \multirow{2}{*}{$\begin{array}{c}\text { HPPI \& Korea } \\
\text { EPUI }\end{array}$} & HPPI $\nRightarrow$ Korea EPUI & 4.017 \\
\hline & Korea EPUI $\nRightarrow \mathrm{HPPI}$ & $12.814^{* * *}$ \\
\hline \multirow{2}{*}{$\begin{array}{c}\text { HLPI \& Korea } \\
\text { EPUI }\end{array}$} & HLPI $\nRightarrow$ Korea EPUI & $6.401^{* *}$ \\
\hline & Korea EPUI $\nRightarrow \mathrm{HLPI}$ & $47.882^{* * *}$ \\
\hline \multirow{2}{*}{$\begin{array}{c}\text { CSI \& Korea } \\
\text { EPUI }\end{array}$} & $\mathrm{CSI} \nRightarrow$ Korea EPUI & 4.079 \\
\hline & Korea EPUI $\nRightarrow \mathrm{CSI}$ & 0.922 \\
\hline \multirow{2}{*}{$\begin{array}{c}\text { BSI \& Korea } \\
\text { EPUI }\end{array}$} & BSI $\nRightarrow$ Korea EPUI & 0.242 \\
\hline & Korea EPUI $\nRightarrow \mathrm{BSI}$ & $5.536^{\star *}$ \\
\hline \multirow{2}{*}{$\begin{array}{c}\text { CPI \& Japan } \\
\text { EPUI }\end{array}$} & CPI $\nRightarrow$ Japan EPUI & 0.344 \\
\hline & Japan EPUI $\nRightarrow$ CPI & 2.025 \\
\hline \multirow{2}{*}{$\begin{array}{c}\text { PPI \& Japan } \\
\text { EPUI }\end{array}$} & PPI $\nRightarrow$ Japan EPUI & 1.081 \\
\hline & Japan EPUI $\nRightarrow$ PPI & 2.299 \\
\hline \multirow{2}{*}{$\begin{array}{c}\text { HPPI \& Japan } \\
\text { EPUI }\end{array}$} & HPPI $\nRightarrow$ Japan EPUI & $5.429^{*}$ \\
\hline & Japan EPUI $\nRightarrow$ HPPI & $8.561^{* \star}$ \\
\hline \multirow{2}{*}{$\begin{array}{l}\text { HLPI \& Japan } \\
\text { EPUI }\end{array}$} & HLPI $\nRightarrow$ Japan EPUI & 4.015 \\
\hline & Japan EPUI $\nRightarrow$ HLPI & $11.450^{* * *}$ \\
\hline \multirow{2}{*}{$\begin{array}{c}\text { CSI \& Japan } \\
\text { EPUI }\end{array}$} & CSI $\nRightarrow$ Japan EPUI & 0.514 \\
\hline & Japan EPUI $\nRightarrow$ CSI & 2.103 \\
\hline \multirow{2}{*}{$\begin{array}{l}\text { BSI \& Japan } \\
\text { EPUI }\end{array}$} & BSI $\nRightarrow$ Japan EPUI & 1.895 \\
\hline & Japan EPUI $\nRightarrow \mathrm{BSI}$ & $8.126^{* \star}$ \\
\hline \multirow{2}{*}{$\begin{array}{l}\text { CPI \& Hong } \\
\text { Kong EPUI }\end{array}$} & $\mathrm{CPI} \nRightarrow$ Hong Kong EPUI & 1.526 \\
\hline & Hong Kong EPUI $\nRightarrow \mathrm{CPI}$ & $7.390^{*}$ \\
\hline \multirow{2}{*}{$\begin{array}{l}\text { PPI \& Hong } \\
\text { Kong EPUI }\end{array}$} & PPI $\nRightarrow$ Hong Kong EPUI & 0.001 \\
\hline & Hong Kong EPUI $\nRightarrow$ PPI & 0.265 \\
\hline \multirow{2}{*}{$\begin{array}{l}\text { HPPI \& Hong } \\
\text { Kong EPUI }\end{array}$} & HPPI $\nRightarrow$ Hong Kong EPUI & 2.186 \\
\hline & Hong Kong EPUI $\nRightarrow \mathrm{HPPI}$ & $16.569^{* *}$ \\
\hline \multirow{2}{*}{$\begin{array}{l}\text { HLPI \& Hong } \\
\text { Kong EPUI }\end{array}$} & HLPI $\nRightarrow$ Hong Kong EPUI & $2.839^{*}$ \\
\hline & Hong Kong EPUI $\nRightarrow \mathrm{HLPI}$ & $14.038^{* * *}$ \\
\hline \multirow{2}{*}{$\begin{array}{l}\text { CSI \& Hong } \\
\text { Kong EPUI }\end{array}$} & CSI $\nRightarrow$ Hong Kong EPUI & 1.067 \\
\hline & Hong Kong EPUI $\nRightarrow \mathrm{CSI}$ & $3.855^{\star \star}$ \\
\hline \multirow{2}{*}{$\begin{array}{l}\text { BSI \& Hong } \\
\text { Kong EPUI }\end{array}$} & BSI $\nRightarrow$ Hong Kong EPUI & $10.913^{* * *}$ \\
\hline & Hong Kong EPUI $\nRightarrow \mathrm{BSI}$ & $10.233^{*}$ \\
\hline \multirow{2}{*}{$\begin{array}{c}\text { CPI \& China } \\
\text { EPUI }\end{array}$} & CPI $\nRightarrow$ China EPUI & 0.144 \\
\hline & China EPUI $\nRightarrow \mathrm{CPI}$ & 0.930 \\
\hline \multirow{2}{*}{$\begin{array}{l}\text { PPI \& China } \\
\text { EPUI }\end{array}$} & PPI $\nRightarrow$ China EPUI & $6.960^{* *}$ \\
\hline & China EPUI $\nRightarrow$ PPI & 0.001 \\
\hline
\end{tabular}




\begin{tabular}{|c|c|c|}
\hline $\begin{array}{c}\text { HPPI \& China } \\
\text { EPUI }\end{array}$ & HPPI $\nRightarrow$ China EPUI & $12.306^{*}$ \\
\cline { 2 - 3 } & China EPUI $\nRightarrow$ HPPI & $9.731^{* *}$ \\
\hline $\begin{array}{c}\text { HLPI \& China } \\
\text { EPUI }\end{array}$ & HLPI $\nRightarrow$ China EPUI & $15.703^{* *}$ \\
\cline { 2 - 3 } & China EPUI $\nRightarrow$ HLPI & $23.267^{* * *}$ \\
\hline $\begin{array}{c}\text { CSI \& China } \\
\text { EPUI }\end{array}$ & CSI $\nRightarrow$ China EPUI & 0.019 \\
\cline { 2 - 3 } & China EPUI $\nRightarrow$ CSI & $6.104^{* *}$ \\
\hline $\begin{array}{c}\text { BSI \& China } \\
\text { EPUI }\end{array}$ & BSI $\nRightarrow$ China EPUI & $3.196^{*}$ \\
\cline { 2 - 3 } & China EPUI $\nRightarrow$ BSI & $4.097^{* *}$ \\
\hline
\end{tabular}

Notes: 1. $\nRightarrow$ means "does not Granger Cause".

2. ${ }^{* * *},{ }^{* *},{ }^{*}$ mean $1 \%, 5 \%$, and $10 \%$ levels.

3. EPUI, CPI, PPI, HPPI, HLPI, CSI, BSI indicate separately Economy Policy Uncertainty Index, Consumer Price Index, Producer Price Index, Housing Purchase Price Index, Housing Lease Price Index, Construction Stock Index, Banking Stock Index.

Optimal lags for VECM are set to lag 1 through the Schwarz-Bayesian Information Criterion (SBIC) as shown in Table 5.

Table 5. Lag order selection.

\begin{tabular}{|c|c|c|c|}
\hline lag & SBIC & HQIC & AIC \\
\hline 0 & -8.939 & -9.033 & -9.096 \\
\hline 1 & $-32.611^{*}$ & -33.636 & -34.330 \\
\hline 2 & -32.136 & -34.092 & -35.417 \\
\hline 3 & -31.269 & -34.156 & -36.113 \\
\hline 4 & -29.610 & -33.428 & -36.017 \\
\hline
\end{tabular}

Notes: $1 .{ }^{*}$ means the optimal lag order.

2. SBIC, AIC, HQIC denote respectively Schwarz-Bayesian Information Criterion, Hannan-Quinn Information Criterion, Akaike Information Criterion.

The results for VECM are shown in Table 6. Korea EPU index has a significant negative relationship to all Korean economic indices except PPI. On the other hand, Japan EPU index has a significant negative relationship only for $\mathrm{CPI}$ and PPI. Hong Kong EPU index has a significant negative relationship only with CSI. China EPU index has a positive relationship with only CSI among Korean economic indexes.
Table 6. Estimation results of VECM.

\begin{tabular}{|c|c|c|c|c|}
\hline & Korea EPUI & $\begin{array}{c}\text { Japan } \\
\text { EPUI }\end{array}$ & $\begin{array}{c}\text { Hong } \\
\text { Kong EPUI }\end{array}$ & China EPUI \\
\hline \multirow{2}{*}{ CPI } & $\begin{array}{c}-0.001^{*} \\
(0.001)\end{array}$ & $\begin{array}{c}-0.002^{*} \\
(0.001)\end{array}$ & $\begin{array}{c}-0.001 \\
(0.001)\end{array}$ & $\begin{array}{c}0.001 \\
(0.001)\end{array}$ \\
\hline \multirow{2}{*}{ PPI } & -0.001 & $-0.003^{*}$ & -0.001 & -0.001 \\
& $(0.001)$ & $(0.002)$ & $(0.001)$ & $(0.001)$ \\
\hline \multirow{2}{*}{ HPPI } & $-0.002^{* *}$ & 0.002 & -0.001 & 0.001 \\
& $(0.001)$ & $(0.001)$ & $(0.001)$ & $(0.001)$ \\
\hline \multirow{2}{*}{ HLPI } & $-0.002^{* *}$ & -0.002 & 0.001 & 0.001 \\
& $(0.001)$ & $(0.002)$ & $(0.001)$ & $(0.001)$ \\
\hline \multirow{2}{*}{ CSI } & $-0.044^{*}$ & -0.045 & $-0.038^{*}$ & $0.033^{* *}$ \\
& $(0.025)$ & $(0.040)$ & $(0.020)$ & $(0.017)$ \\
\hline \multirow{2}{*}{$\mathrm{BSI}$} & $-0.058^{* * *}$ & 0.012 & -0.013 & 0.024 \\
& $(0.022)$ & $(0.036)$ & $(0.018)$ & $(0.015)$ \\
\hline
\end{tabular}

Notes: $1 .{ }^{* * *},{ }^{* *},{ }^{*}$ mean $1 \%, 5 \%$, and $10 \%$ levels.

2. standard errors are in parentheses.

\subsection{Impulse Responses}

\subsubsection{Impulse response of EPU index in Korea}

After impact on Korea EPU index in Fig. 3, the CPI response curve initially falls to negative and reaches the lowest point in the first period. The decline in Korea EPU index stimulates CPI demand. The reaction from the second to the positive reaches the peak in the fourth period. The PPI has been declining negatively from the beginning and continues to have a downward curve. The HPPI declined after the shock of Korea EPU index, but after going over one period, it turned to positive, and it continued to rise. It can be seen that HLPI also moves to a trend of a type similar to HPPI. In the early period, it fell to the negative, and after the second period, it was converted to the positive and the gentle rise. CSI initially fell to negative, but before reaching the second stage, it was converted to positive and then increased as time went on. The BSI also fell in the early period but turned to positive in the second period and continued to rise moderately.

\subsubsection{Impulse response of EPU index in Japan}

Japan After the shock to EPU index in Fig. 3, the CPI response curve initially falls to negative and reaches the lowest point in the first period. After passing through the first period, it is converted to the echoes of the sheep, and the third is kept at the peak and then the gentle descending curve is drawn. The PPI initially falls to negative and reaches the lowest point in the first period. In the second phase, it switched to positive and peaked at the sixth stage and has a gentle descent curve. The HPPI has risen from its earliest to the positive, peaking at the first stage, and slowly repeating the rise and fall in the range of quantities. The HLPI has begun to be positive from the beginning and 
continues to rise in the positive direction. CSI has fallen to negative territory from the beginning, but it has risen to the first stage and has been downgrading to the second stage. The BSI has a negative response curve from the beginning to a steady downward reaction curve.

\subsubsection{Impulse response of EPU index in Hong Kong}

The CPI initially started with a positive amount, then converted to a negative value in the eleventh period, and eventually converged into a positive amount at the end as Fig. 3. The PPI starts to rise in quantity, reaches its peak in fourth period, declines to negative in ninth, and has a gradual downward curve. The HPPI starts from the beginning and declines from the beginning, and then rises from the second period to the fourth period and has a gentle upward curve. The HLPI starts from the beginning to the beginning and falls sharply down to the third period, but then gradually rises and falls repeatedly. CSI starts from the beginning and starts to increase in quantity until the second
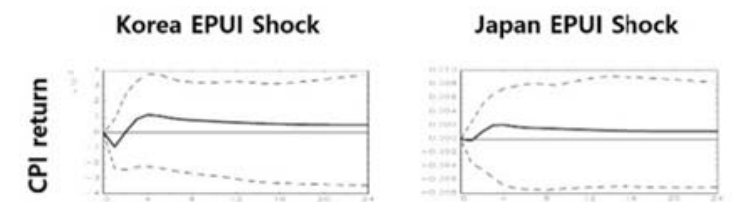

Hong Kong EPUI Shock
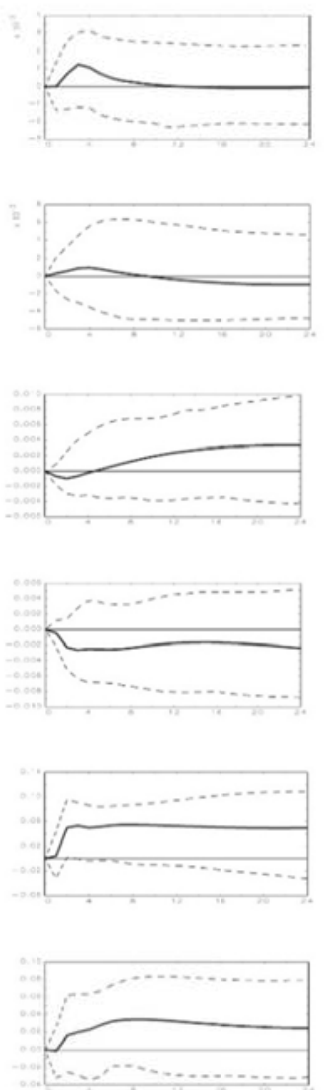

Months

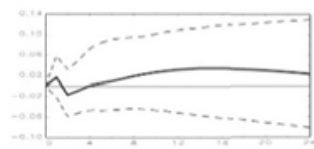

China EPUI Shock
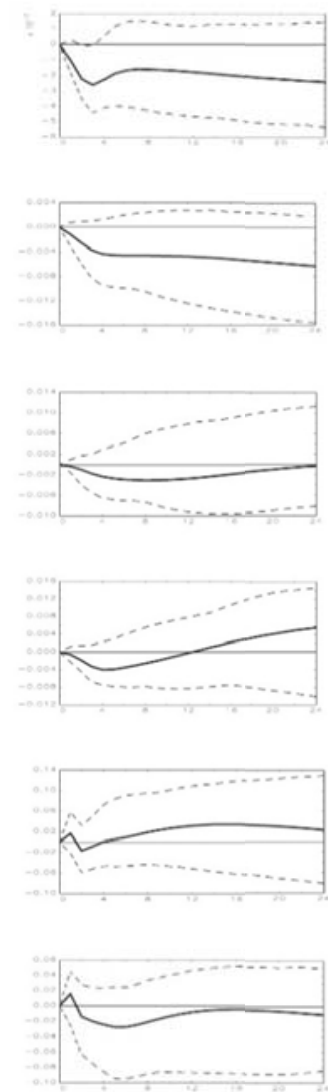

Months

Note: The thick line means the impulse response. And the dotted line means 95\% confidential interval.

Figure 3. Impulse response functions to EPU index shocks of the Korea, Japan, Hong Kong and China 


\section{Conclusions}

\subsection{Summary of results}

In this study, we examine the impact of economic uncertainty in Korea, Japan, Hong Kong and China on the housing market in Korea from January 1999 to December 2016. In this study, uncertainty in economic policy is found in Baker et al. (2016), which is based on the EPU index of each country. The housing market in Korea uses HPPI and HLPI to know the home sale and lease price and analyses the overall housing market economy through the housing stock and financial stock index linked to house price index.

As the results of the Granger causality test, the Korea EPU index has a causal relationship valid for the rest of Korea's CPI, HPPI, HLPI, and BSI except PPI and CSI. Japan EPU index has a causal relationship valid for Korea's HPPI, HLPI, and BSI. The Hong Kong EPU index has a causal relationship valid for all other Korean economic index variables except PPI. China EPU index has a causal relationship to all other economic index variables except $\mathrm{CPI}$ and PPI. This shows that all four Asian countries have a causal relationship valid for HPPI, HLPI, and BSI, which represent Korea's housing market.

In the result of VECM, Korea EPU index has a significant negative relation to all economic index except PPI. On the other hand, Japan EPU index has a significant negative relationship only for $\mathrm{CPI}$ and $\mathrm{PPI}$. Hong Kong and China are found to have significant positive and negative relations with respect to $\mathrm{CSI}$, and interesting results are obtained. We analyze the impact of the shocks proposed by Sims (1980) through economic policy uncertainties. Impulse response function shows that Korea EPU index has a significant negative response to all economic indices. On the other hand, EPU index in other countries are different.

\subsection{Implications}

Through this study, we examine the effect of economic uncertainty on Korea, Japan, Hong Kong, and China on the Korean housing economy. First of all, Korea's housing market is more affected by Korea than Japan, Hong Kong and China. It can be seen that the Korean housing market is more sensitive to policy changes than other countries in connection with the Korean government 's housing policy. This study differs from the existing research as follows.

First, this study shows the economic policy uncertainty index of the Korea has the negative relationships on the housing market economy rather than other countries via VECM analysis. Second, this study has an important evidence of the spillover of several macroeconomic indicators in Korea for the economic policy uncertainty index of the Asian four countries.

\subsection{Limitations and future studies}

This study can be extended to the US or European countries besides the Asian countries because it affects Korea 's housing economics on economic policy uncertainty only in four Asian countries. In addition, this study contributes to the Korean economy in that, if carefully observing economic uncertainty in Korea and other four Asian countries, the Korean economy as well as the housing market can be predicted more closely.

\section{References}

Antonakakis, N., \& Floros, C. (2016). Dynamic interdependencies among the housing market, stock market, policy uncertainty and the macroeconomy in the United Kingdom. International Review of Financial Analysis, 44(1), 111-122.

Aoki, K., Proudman, J., \& Vlieghe, G. (2004). House prices, consumption, and monetary policy: A financial accelerator approach. Journal of Financial Intermediation, 13(4), 414-435.

Backé, P., \& Wójcik, C. (2008). Credit booms, monetary integration and the new neoclassical synthesis. Journal of Banking \& Finance, 32(3), 458-470.

Baker, S. R., Bloom, N., \& Davis, S. J. (2016). Measuring economic policy uncertainty. Quarterly Journal of Economics, 131(4), 1593-1636.

Beltratti, A., \& Morana, C. (2010). International house prices and macroeconomic fluctuations. Journal of Banking \& Finance, 34(3), 533-545.

Bittlingmayer, G. (1998). Output, stock volatility, and political uncertainty in a natural experiment: Germany. Journal of Finance, 53(6), 2243-2257.

Bloom, N. (2009). The Impact of uncertainty shocks. Econometrica, 77(3), 623-685.

Boutchkova, M., Doshi, H., Durnev, A., \& Molchanov, A. (2012). Precarious politics and return volatility. Review of Financial Studies, 25(4), 1111-1154.

Buckley, R., \& Ermisch, J. (1982). Government policy and house prices in the United Kingdom: an econometric analysis. Oxford Bulletin of Economics and Statistics, 44(4), 273-304.

Calcagno, R., Fornero, E., \& Rossi, M. C. (2009). The effect of house prices on household consumption in Italy. Journal of Real Estate Finance and Economics, 39(3), 284-300. 
Campbell, J., \& Cocco, J. (2007). How do house prices affect consumption? evidence from micro data. Journal of Monetary Economics, 54(3), 591-621.

Chang, T., Chen, W., Gupta, R., \& Nguyen, D. K. (2015). Are stock prices related to the political uncertainty index in OECD countries? evidence from the bootstrap panel causality test. Economic Systems, 39(2), 288-300.

Chung, E., \& Haurin, D. R. (2002). Housing choices and uncertainty: the impact of stochastic events. Journal of Urban Economics, 52(2), 193-216.

Döpke, J., \& Pierdzioch, C. (2006). Politics and the stock market: evidence from Germany. European Journal of Political Economy, 22(4), 925-943.

Dougherty, A., \& Order, R. V. (1982). Inflation, housing costs, and the consumer price index. American Economic Review, 72(1), 154-164.

Engle, R. F., \& Granger, C. W. J. (1987). Co-integration and error correction: Representation, estimation, and testing. Econometrica, 55(2), 251-276.

Englund, P., \& loannides, Y. M. (1997). House price dynamics: An international empirical perspective. Journal of Housing Economics, 6(2), 119-136.

Granger, C. W. J. (1980). Testing for causality: a personal viewpoint. Journal of Economic Dynamics and Control, 2(4), 329-352.

Granger, C. W. J. (1981). Some properties of time series data and their use in econometric model specification. Journal of Econometrics, 16(1), 121-130.

Granger, C. W. J., \& Newbold, P. (1974). Spurious regression in econometrics. Journal of Econometrics, 2(1), 111-120.

lacoviello, M., \& Minetti, R. (2006). The credit channel of monetary policy: Evidence from the housing market. Journal of Macroeconomics, 30(1), 69-96.

Johansen, S. (1988). Statistical analysis of cointegration vectors. Journal of Economic Dynamics and Control, 12(1), 231-254.

Jeon, J. (2017). The impact of economic policy uncertainty on commodity price in Korea, the U.S. and Japan. Journal of Distribution Science, 13(1), 243-262.
Jeon, J., Lee, H., \& Lee, C. (2017). Economic policy uncertainty and Korean economy: Focusing on distribution industry stock market. Journal of Distribution Science, 15(12), 41-51.

Jeong, D. (2017). Forecasting for a Credit Loan from Households in South Korea. International Journal of Industrial Distribution \& Business, 8(4), 15-21.

Jian, G. (2012). An Empirical Analysis on Urban Consumption Structure in Shandong Province, China. East Asian Journal of Business Management, 2(2), 23-26.

Julio, B., \& Yook, Y. (2012). Political uncertainty and corporate investment cycles. Journal of Finance, 67(1), 45-83.

Mei, J., \& Guo, L. (2004). Political uncertainty, financial crisis, and market volatility. European Financial Management, 10(4), 639-657.

Rahman, M. M. (2010). The Australian housing marketunderstanding the causes and effects of rising prices. Policy Studies, 31(5), 577-590.

Sims, C. (1980). Macroeconomics and reality, Econometrica, 48(1), 1-48.

Su, D., Li, X., Lobont, O. R., \& Zhao, Y. (2016). Economic policy uncertainty and housing returns in Germany: evidence from a bootstrap rolling window. Journal of Economics and Business, 34(1), 43-61.

Wang, P., \& Kim, J. (2014). The value of reverse mortgage loans: Case study of the Chinese market. Journal of Asian Finance, Economics and Business, 1(4), 5-13.

$\mathrm{Yu}$, H. (2008). Government policies and housing price instability. Public Policy Review, 22(2), 74-115.

Yu, H., \& Lee, S. (2010). Government housing policies and housing market instability in Korea. Habitat International, 34(2), 145-153.

Zhang, H., Li, S., \& Kong, Y. (2016). Elasticity of demand for urban housing in western China Based on micro-data - A case study of Kunming. International Journal of Industrial Distribution \& Business, 7(3), 27-36. 